\title{
Deposit Withdrawal Behavior of Islamic Banking Customers in Brunei Darussalam
}

\author{
Muhamad Abduh, University of Brunei Darussalam, Bandar Seri Begawan, Brunei Darussalam \\ iD https://orcid.org/0000-0002-1918-6525
}

\begin{abstract}
This article is aimed at investigating the deposit withdrawal behavior of Islamic banking customers in Brunei Darussalam. More specifically, it explores the influence of individual characteristics upon the action of deposit withdrawal when the customers encounter three different situations: (i) non-shariah compliance issues upon products and services; (ii) uncompetitive return; and (iii) low service quality. Data collection is done using self-administered questionnaires with 180 completed questionnaires used for the analysis. The study uses a chi-squared independent test and binary logistic regression as its method of analysis. The findings show that deposit withdrawal is a real future threat for the Islamic banking industry in Brunei Darussalam and it happens when customers with certain characteristics and motivations encounter the three situations mentioned above.
\end{abstract}

\section{KEYWORDS}

Brunei Darussalam, Customer Behavior, Deposit Withdrawal, Islamic Banking, Logistic Regression

\section{INTRODUCTION}

Brunei Darussalam is one of the smallest country in the world with total area of 5765-sq KM. The country is directly facing the South China Sea and the rest are bounded by Malaysia. The latest census mentions that the population of Brunei is around 450,000 persons with more than half of the population is Malay and Muslim. The official religion is Islam with His Majesty the Sultan and Yang Di-Pertuan as the head of the Islamic faith in the country. Hence, Islam plays a central role in the life of every Muslim in Brunei Darussalam.

The influence of Islam can also be sensed in the financial sectors of the country. Brunei Darussalam is among the earliest country in the world adopting Islamic banking system after Malaysia, Pakistan, Sudan and Iran. Currently, Bank Islam Brunei Darussalam (BIBD) is the only Islamic commercial bank in Brunei Darussalam that serves all segments within the retail banking market (Abduh, 2018). The bank was started in 1981 as the Island Development Bank and then converted to a full-fledged Islamic bank in January 1993 and changed its name to Islamic Bank of Brunei (IBB). There was a big merger in the history of Brunei financial system in 2005 between IBB and the Islamic Development Bank of Brunei which leads to the inception of BIBD. 
Brunei is running the Islamic and conventional banking system in parallel. Despite its small population and area, there are currently four local banks and five foreign banks provide services here (Table 1). However, only three banks provide Islamic contracts for their saving and financing schemes. Those banks are local and namely BIBD, Perbadanan Tabung Amanah Islam Brunei (TAIB), and recently established Bank Usahawan. Other banks are operated under conventional banking schemes.

Interestingly, despite Islam as the official religion of the country and the religion of majority of the Bruneian, the two biggest local banks, Baiduri as a conventional bank and BIBD as an Islamic bank, are having a strong competition among them and shared almost equal number of customers. According to the findings from Abduh (2016), one of the reasons is because the understanding about riba among the Bruneian is still low. Furthermore, this is also because both Islamic and conventional banks operating in Brunei are offering similar products and following almost similar regulations set by the monetary authority of Brunei Darussalam.

For Islamic banking, keeping deposits stable and large, without any significant fluctuation, is one of its major concerns in achieving successfulness (Abduh, 2011). However, it is not always easy since Brunei is among the countries offering Islamic and conventional banking products and services in parallel. Therefore, as argued by Ahmed (2002), in a country with dual banking system like Brunei Darussalam, the Islamic banks are facing withdrawal risk as the return on customer deposits can vary. Not only that, studies had confirmed that service quality provides high influence upon customers' decision of either remain with current banks or move to other banks which provide better service quality. Moreover, as far as the Islamic banking is concerned, the customers are not only looking for profits but rather the compliance of products and services towards shariah tenets. Therefore, there will be a tendency of withdrawing from the bank when it violates those tenets.

Hence, the objective of this study is to investigate the deposit withdrawal behavior among Islamic banking customers. More specifically, this study tries to identify the individual characteristics which may affect the behavior of Islamic banking customers towards the issues of shariah non-compliancy, the fluctuation of returns and service quality provided by Islamic banks in Brunei Darussalam.

The rest of this paper discusses four other parts. Chapter two provides previous literature on the area discussed and chapter three describes the data and methods used for the analysis utilized in this study. Furthermore, the discussion of the findings and conclusions will be discussed in chapter four and five respectively.

Table 1. List of banks in Brunei Darussalam

\begin{tabular}{|l|l|l|}
\hline \multicolumn{1}{|c|}{ Name of the Bank } & \multicolumn{1}{c|}{ Ownership } & \multicolumn{1}{c|}{ Type } \\
\hline Baiduri Bank & Local & Conventional \\
\hline Bank Islam Brunei Darussalam & Local & Islamic \\
\hline $\begin{array}{l}\text { Perbadanan Tabung Amanah Islam } \\
\text { Brunei }\end{array}$ & Local & Islamic \\
\hline Bank Usahawan & Local & Islamic \\
\hline Maybank & Foreign & Conventional \\
\hline RHB Bank & Foreign & Conventional \\
\hline Standard Chartered Bank & Foreign & Conventional \\
\hline Bank of China & Foreign & Conventional \\
\hline UOB Bank & Foreign & Conventional \\
\hline
\end{tabular}




\section{LITERATURE REVIEW}

\section{Deposit Withdrawal in Islamic Banking}

Iqbal et.al. (1998) mentions that initially there were two models developed for Islamic banking system and operation, namely two-tier mudarabah model and one-tier mudarabah model. The former means that Islamic bank replaces the interest with profit sharing upon the liability and the asset side while the latter means that the bank takes the form of profit sharing upon the liability side only, and uses fixed income upon the asset side. Nevertheless, only the latter model adopted in most countries having Islamic banking today. According to Ahmed (2002), the main reason why two-tier mudarabah fails and one-tier mudarabah model evolves is due to the challenges faced by Islamic banks in practical and operational in using profit sharing modes on the asset side.

Rewarding customers using profit sharing is a distinctive feature of Islamic banking industry which has changed the nature of risks. Since conventional banks use loan contract as demand deposits and its repayment is assured, then they will only face conventional financial risks. However, because Islamic banks use profit sharing for return in deposits, they eliminate financial risks but at the same time introduce some other risks. Firstly is displaced commercial risk which takes place when the profit sharing paid to customers is the outcome of a combination between conservative investment strategies and the use of reserve accounts formed out of profits to smoothen the profit payouts and to cover periodic losses (Archer and Karim, 2009). Secondly, since customers are intended to protect their assets' real value, the withdrawal risk due to lower rate of return is a new and unique risk of Islamic banks when they use profit sharing modes on liability side (Ahmed, 2002).

When customers see that returns at all banks are declining due to economic recession, the probability of customers to withdraw and move to other banks is very small. However, if the poor performance is restricted to a single bank only, the reaction of customers will not be the same. A secluded low return performance of the bank is a signal of mismanagement for customers and thus, the probability of deposit withdrawals is higher.

However, the findings from Abduh (2017) had also suggested that Islamic banking customers are divided into two, i.e. rational and religious depositors. Rational customers are said to be more profit oriented, while religious customers have given more attention to shariah issues before they deposit their money in a bank. Therefore, another driving factor for customers to withdraw their deposits from an Islamic bank is when there is an issue of breaching upon shariah tenets.

\section{Previous Related Studies}

In the conventional banking framework, Beerli et al. (2004) found that in Spain, customers are reluctant to withdraw and move to other banks when they are satisfied with services provided. In addition, customers are also considering to remain with current banks when the cost to open new accounts in other bank is more expensive. Similarly in Pakistan, Afsar et al. (2010) evidenced a negative and significant association between satisfaction and switching cost as independent variables toward customer withdrawal behavior as dependent variable.

Gerard and Cunningham (2001) recorded seven types of incidents which cause customers to leave their bank which can be concluded as service failures and over pricing. Those incidents are (i) core service failures; (ii) service encounter failures; (iii) employee responses to service failures; (iv) inconveniences; (v) attraction by competitors; (vi) over pricing; and (vii) ethical problems.

In the United States, Gilkeson and Ruff (1996) and Gilkeson et al. (1999) studied the customers' early withdrawal evidence of their banks' time deposits. The former found that investment incentives played as the motivating factor of the customers' early deposit withdrawals. However, the latter found the opposite results. Gilkeson et al. (1999) evidenced that instead of higher return on investment, early deposit withdrawals are motivated by bank customers' liquidity needs. The study also confirmed that the fluctuation of total deposit is significantly sensitive to changes in interest rates. On another occasion, Currie (2004) found that demand deposits in the US are prone to all forces that affected 
the volume of media of exchange of the community whereas time deposits, on the other hand, are affected more by factors that affecting saving and investing.

In the Islamic banking framework, Ahmed (2002) found that deposit withdrawal is driven by customers' intention to preserve their assets by minimizing the risk of losses due to a lower rate of return. To support his findings, Ahmed (2003) conducted a survey in following year involving 468 respondents in three different countries i.e. Sudan, Bangladesh, and Bahrain. The result found four reasons motivating depositors to withdraw their deposit which are: (i) rumors about the poor performance of Islamic banks; (ii) implementation of non-sharia compliance products and practices; (iii) some parts of the banks' income were from interest income; and (iv) lower return.

In Malaysia, Abduh et al. (2011) used cointegration and vector error correction model to analyze the long- and short-run dynamics of the changes of conventional bank's interest rate and Islamic bank's profit rate, level of production, level of inflation and financial crisis upon the variation of total deposits in Malaysian Islamic banks. The findings have shown that there is no significant impact of the changes in interest and profit rate as well as production growth towards total Islamic banking deposit. However, financial crisis is interestingly provides positive impact towards total deposits which means that in general, total deposit of Islamic banks increases during the financial crisis. On the other hand, total deposit is negatively affected by inflation which reflects the changes of consumer's consumption during the economic recession. The findings from Haron and Ahmad (2000) were in favor of Ahmed (2002) and Ahmed (2003). The study found a positive relationship between Islamic banking deposit rate and the total deposits.

In Indonesia, Abduh (2015) examined factors influencing Islamic banking's deposit level using cointegration and impulse response functions. Contrary to Abduh et al. (2011), this study revealed that the changes in conventional banking's interest rate considered as one of the main driving factors for deposit withdrawal in Islamic banks. Furthermore, this study found no significant impact of financial crisis upon the volatility of Islamic banking's deposit. This implies that customers have a strong believe towards the resilience of Islamic banks against financial crisis. Nonetheless, the result also indicated that.

Based on the previous studies reported above, there are three major issues for deposit withdrawal action in Islamic banking industry i.e. bank's service quality, interest or profit rate, and shariah issues. However, this study is different from previous literature in a sense that it does not looking for factors driving the fluctuation of Islamic banking deposit but rather finding which group of customers affected by those three major causes and thus shall produce intention to withdraw their deposit in the near future. The dependent and independent variables are explained in the following section.

\section{DATA AND METHODS OF ANALYSIS}

\section{Data}

This study is using primary data collected from Islamic banking customers in Bandar Seri Begawan. Due to limited information upon the size of the population and how to locate them, the sampling technique adopted is non-probability convenience sampling where potential respondents are filtered based upon the screening question of "do you have an Islamic bank account?". They become our respondents if the answer of the screening question is "Yes" and they are willing to participate in the study anonymously.

With the culture among Bruneian whose tend to not disclose any information about themselves to outsiders, the researchers are very fortunate to gather more than 200 questionnaires with 180 questionnaires which were fully filled by the respondents and thus used in the analysis. Before going to the main analysis, the data will be analyzed using simple descriptive statistics and then followed by cross-tabulation of the chi-squared independent test. Finally, the main analysis is done using binary logistic regression analysis. 
The independent variables used in the binary logistic regression analysis are the combination of customers' demography i.e. gender, religion, marital status, education level and possession of conventional banking account; and motivation to patronize Islamic bank i.e. to avoid riba, to obtain better return, and to experience better service quality.

Table 3 summarizes the dependent variables used in this study and each of them will represent one model. Model 1 is a logistic regression model using variables in Table 2 as the independent variables and variable Y1 in Table 3 as the dependent variable. Model 2 and Model 3 are the logistic regression model using variables in Table 2 as the independent variables and variable Y2 and Y3 in Table 3 respectively as the dependent variables. In order to make it compatible with binary logistic regression technique, the data are collected in binomial basis $(1,0)$ as shown in Table 2 and Table 3 .

\section{Logistic Regression}

The objective of this study is to investigate the relationship between individual's attributes like gender, education level, age group and motivations to patronize Islamic banks with their deposit withdrawal behavior, particularly in Islamic bank. Similar to the independent variables, the dependent variables are also in binomial form whereby code 1 means to withdraw and code 0 means not to withdraw for the time when they responded.

Abduh, et.al. (2012) mentions that for a dichotomous dependent variable, despite a number of distribution models available as the method of analysis, the most widely used is the logistic model. In support of the usage of logistic model, Hosmer and Lemeshow (2000) provides two main motives for selecting the logistic distribution. Firstly, it is a flexible and easily used mathematical function. Secondly, the model provides meaningful interpretation.

In a linear regression, it is assumed that the mean may be expressed as a linear equation in $\mathrm{x}$ (or some transformation of $\mathrm{x}$ or $\mathrm{Y}$ ), such as:

Table 2. List of independent variables

\begin{tabular}{|l|l|}
\hline \multicolumn{1}{|c|}{ Variable } & \multicolumn{1}{c|}{ Explanation } \\
\hline $\mathrm{X} 1$ & Gender $(1=$ Male; $0=$ Female $)$ \\
\hline $\mathrm{X} 2$ & Religion $(1=$ Islam; $0=$ otherwise $)$ \\
\hline $\mathrm{X} 3$ & Marital status $(1=$ Married; $0=$ otherwise $)$ \\
\hline $\mathrm{X} 4$ & Education level $(1=$ Post graduate; $0=$ otherwise $)$ \\
\hline $\mathrm{X} 5$ & Return as the main motivation $(1=$ Yes; $0=$ otherwise $)$ \\
\hline $\mathrm{X} 6$ & Avoid riba as the main motivation $(1=$ Yes; $0=$ otherwise $)$ \\
\hline $\mathrm{X} 7$ & Service quality as the main motivation $(1=$ Yes; $0=$ otherwise $)$ \\
\hline X8 & Has conventional banking account $(1=$ Yes; $0=$ otherwise $)$ \\
\hline
\end{tabular}

Table 3. List of dependent variables

\begin{tabular}{|l|l|l|}
\hline \multicolumn{1}{|c|}{ Variable } & \multicolumn{1}{c|}{ Description } & \multicolumn{1}{c|}{ Response } \\
\hline Y1 & Non-Shariah Compliance issues & $\begin{array}{l}1=\text { I will Withdraw } \\
0=\text { Otherwise }\end{array}$ \\
\hline Y2 & Uncompetitive Rate of Return & $\begin{array}{l}1=\text { I will Withdraw } \\
0=\text { Otherwise }\end{array}$ \\
\hline Y3 & Low Service Quality & $\begin{array}{l}1=\text { I will Withdraw } \\
0=\text { Otherwise }\end{array}$ \\
\hline
\end{tabular}




$$
E(Y \mid x)=\beta_{0}+\beta_{1} x
$$

which shows the possibility for $E(Y \mid x)$ to take nay values as $\mathrm{x}$ ranges between $-\infty$ to $+\infty$. However, the specific model used in logit regression is:

$$
E(Y \mid x)=\pi(x)=\frac{e^{\beta_{0}+\beta_{1} x}}{1+e^{\beta_{0}+\beta_{1} x}}
$$

where:

$\mathrm{e}=$ Euler's number(2.7183)

$$
\pi(x)=\text { function of } \mathrm{x} \text { in logit model }
$$

Furthermore, in order to provide a meaningful interpretation, $E(Y \mid x)$ is transformed with logit transformation to become:

$$
g(x)=\ln \left[\frac{\pi(x)}{1-\pi(x)}\right]=\beta_{0}+\beta_{1} x
$$

Now $\mathrm{g}(\mathrm{x})$ has many of the desirable properties of a linear regression model. The logit, $\mathrm{g}(\mathrm{x})$ is now linear to its parameter. Therefore, the linear relationship of dependent - independent variables in this study can be expressed in the following equations:

$$
\begin{aligned}
& p=\exp \left[a+\beta_{1} x_{1}+\ldots+\beta_{8} x_{8}\right] /\left(1+\left[a+\beta_{1} x_{1}+\ldots+\beta_{8} x_{8}\right]\right) \\
& \log \left(\frac{p}{1-p}\right)=a+\beta_{1} x_{1}+\ldots+\beta_{8} x_{8}
\end{aligned}
$$

The significance of the independent variables that can be included in the model is assessed by comparing observed values of the response variable with predicted values obtained from models. A non-significant likelihood ratio test indicates no difference between the full and the reduced models. Henceforth, it will justify the dropping of the given variable in order to have a thriftier model that works just as well.

\section{FINDINGS AND DISCUSSION}

\section{Descriptive and Chi-Squared Independent Test}

Based on the statistic displayed in Table 4, as many as 80 percent of the respondents are female and 20 percent are male. As many as 58.3 percent of our respondents are below 25 years old and 41.1 percent are between 25 and 35 years old. Furthermore, 87.2 percent are Muslims and 96.1 percent are not married. Another important statistic is the respondents' level of education. It is also shown that 107 
respondents (59.4\%) are postgraduate degree holders and $73(40.6 \%)$ respondents are undergraduate degree holders. This shows that our respondents are educated and well-informed customers about banking products and services. Table 4 also displays that respondents with multiple banking accounts are 107 (59.4\%) and the respondent with single banking account are 73 (40.6\%).

With all respondents are holding at least undergraduate degree and having at least single Islamic banking account, the statistics confirm that respondents are mature and possess basic knowledge of banking so that their responses upon the questions are considerably reliable. Moreover, the authors believe that responses from respondents possessing both Islamic and conventional banking account will bring more information in this study.

With regard to bank customers' motivations for withdrawing their deposits, findings from Abduh (2014) suggest that deposit withdrawal action in Islamic banking framework is driven by three issues; (i) non-Shari' ah compliant issues, (ii) uncompetitive rate of return, and (iii) rumors about incoming global financial crisis that could affect the performance of their patronized Islamic bank. However, due to the fact that Brunei was not really affected by the global financial crises in 1997-1998 and 2007-2008, this study is focused only on the first two motivations and had replaced the third motivation to service quality issues as displayed in Table 5.

Table 4. Demography of respondents

\begin{tabular}{|c|c|c|c|}
\hline \multicolumn{2}{|c|}{ Variable } & \multirow[t]{2}{*}{ Frequency } & Percentage $(\%)$ \\
\hline \multirow{2}{*}{ Gender } & Male & & 20 \\
\hline & Female & 144 & 80 \\
\hline \multirow{3}{*}{ Age } & $<25$ years & 105 & 58.3 \\
\hline & $25-35$ years & 74 & 41.1 \\
\hline & $>35$ years & 1 & 0.6 \\
\hline \multirow{2}{*}{ Religion } & Islam & 157 & 87.2 \\
\hline & Others & 23 & 12.8 \\
\hline \multirow{2}{*}{ Marital Status } & Married & 7 & 3.9 \\
\hline & Not Married & 173 & 96.1 \\
\hline \multirow{2}{*}{ Level of Education } & Undergraduate & 73 & 40.6 \\
\hline & Postgraduate & 107 & 59.4 \\
\hline \multirow{2}{*}{ Have conventional bank account } & Yes & 107 & 59.4 \\
\hline & No & 73 & 40.6 \\
\hline
\end{tabular}

Table 5. Motivations for withdrawing deposit from Islamic banks

\begin{tabular}{|l|l|l|l|}
\hline \multirow{2}{*}{\multicolumn{1}{|c}{ Decision }} & \multicolumn{2}{c|}{ Motivation to Withdraw } \\
\cline { 2 - 4 } & $\begin{array}{c}\text { Non-Shari'ah Compliant } \\
\text { Issues }\end{array}$ & $\begin{array}{c}\text { Uncompetitive Rate of } \\
\text { Return }\end{array}$ & \multicolumn{1}{c|}{ Low Service Quality } \\
\hline I will withdraw & $100(55.6 \%)$ & $101(56.1 \%)$ & $143(79.4 \%)$ \\
\hline I will not withdraw & $80(44.4 \%)$ & $79(43.9 \%)$ & $37(20.6 \%)$ \\
\hline Total & 180 & 180 & 180 \\
\hline
\end{tabular}


Awareness upon the local and international jurists' opinion about the status of bank interest from the Islamic point of view provides a significant impact towards the decision of many Muslims on their bank selection criteria (Abduh and Omarov, 2013; Mahmoud and Abduh, 2014). Thus, as anticipated, Table 5 shows a significant number of 55.6 percent of the respondents decide to withdraw their deposits from Islamic bank if they encounter issues of non-shari'ah compliant products and services. Interestingly, as many as 56.1 percent of the respondents say that they will also withdraw their deposits due to uncompetitive rate of return from Islamic bank. However, low service quality has gained the highest percentage of 79.4 percent for being the cause of respondents' decision to withdraw their deposit. This implies that Islamic banks must not only focused on how make things shariah compliance but also profitable. On top of that, Islamic banks must also be able to improve their service quality gradually in order to meet the expectation of their customers.

In order to find the relationship between the respondents' main motivation of patronizing Islamic bank and their deposit withdrawal decision when those things are not met, this paper provides deeper analysis by running the chi-squared independent test via cross tabulation. Table 6 shows that according to the chi-squared independent test, respondents who put "to avoid bank interest" as their main motivation in patronizing Islamic banks intend to withdraw their funds if they encounter a situation where their Islamic bank is involved with non-Shari' ah compliant issues; either in products or services. Similarly, there is also a strong evidence that respondents who consider Islamic bank as an alternative to gain more profit will withdraw their funds from Islamic bank due to lower return or higher charges imposed for services provided.

With regard to the third motivation, it is very interesting to find that Islamic banking customers in Brunei Darussalam consider shariah issues as an important part of service quality. Therefore, those who are putting good service quality as the main motivating factor to patronize an Islamic bank would be willing to withdraw their deposits either due to low service quality or non-shariah compliance issues. This also implies that shariah tenets must not only applied in products per se but also in other aspects of services such as staff dress code or appearances, sympathy and politeness, and speed of responding complaints or feedbacks.

\section{Logit Models}

Table 7 provides estimated coefficients and odd-ratios for all variables in all logit models developed. For Model 1 where Y1 is non-Shariah compliance, the significant predictors are Gender X1(1), Religion X2(1), patronizing Islamic bank is to avoid riba X6(1) and patronizing Islamic bank to experience better service quality X7(1). In addition, its Nagelkerke R-Square is 0.27 and its chi-squared for Hosmer-Lemeshow Test is 19.156. The Nagelkerke R-Square of 0.27 indicates that $27 \%$ of variation

Table 6. $\mathrm{X}^{2}$ independent test between motivation of patronizing Islamic bank and withdrawal action

\begin{tabular}{|c|c|c|c|c|c|c|c|c|c|c|}
\hline \multirow{2}{*}{\multicolumn{2}{|c|}{ Motivation }} & \multicolumn{2}{|c|}{$\begin{array}{c}\text { Non-Shari'ah } \\
\text { Compliant Issues }\end{array}$} & \multirow[t]{2}{*}{$\chi^{2}$-Stat } & \multicolumn{2}{|c|}{$\begin{array}{l}\text { Uncompetitive } \\
\text { Rate of Return }\end{array}$} & \multirow[t]{2}{*}{$\chi^{2}$-Stat } & \multicolumn{2}{|c|}{$\begin{array}{c}\text { Low Service } \\
\text { Quality }\end{array}$} & \multirow[t]{2}{*}{$\chi^{2}$-Stat } \\
\hline & & W & N-W & & $\mathbf{W}$ & N-W & & W & N-W & \\
\hline \multirow{2}{*}{$\begin{array}{l}\text { To avoid bank } \\
\text { interest }\end{array}$} & Yes & 85 & 50 & \multirow{2}{*}{$12 * *$} & 71 & 64 & \multirow{2}{*}{2.72} & 104 & 31 & \multirow{2}{*}{1.92} \\
\hline & No & 15 & 30 & & 30 & 15 & & 39 & 6 & \\
\hline \multirow{2}{*}{$\begin{array}{l}\text { Competitive } \\
\text { Rate of Return }\end{array}$} & Yes & 50 & 43 & \multirow{2}{*}{0.25} & 64 & 29 & \multirow{2}{*}{$12.6 * *$} & 77 & 16 & \multirow{2}{*}{1.32} \\
\hline & No & 50 & 37 & & 37 & 50 & & 66 & 21 & \\
\hline \multirow{2}{*}{$\begin{array}{l}\text { Good Service } \\
\text { Quality }\end{array}$} & Yes & 54 & 64 & \multirow{2}{*}{$13.3^{* *}$} & 68 & 50 & \multirow{2}{*}{0.32} & 100 & 18 & \multirow{2}{*}{$5.89 *$} \\
\hline & No & 46 & 16 & & 33 & 29 & & 43 & 19 & \\
\hline
\end{tabular}

Note: "W" means Withdraw, "N-W" means Not Withdraw.

${ }^{*}$ and ${ }^{* \star}$ are to show significant relationship at alpha $5 \%$ and $1 \%$, respectively. 
Table 7. Estimated coefficients ( $\beta$ ) and odd-ratio (Exp.( $\beta))$ for all logit models

\begin{tabular}{|c|c|c|c|c|c|c|}
\hline \multirow[t]{2}{*}{ Variable } & \multicolumn{2}{|c|}{$\begin{array}{c}\text { Model } 1 \\
\mathbf{Y}=\text { Non-Shariah } \\
\text { Compliance }\end{array}$} & \multicolumn{2}{|c|}{$\mathbf{Y}=\underset{\substack{\text { Uncodel 2 } \\
\text { Return }}}{\text { Rncompitive }}$} & \multicolumn{2}{|c|}{$\begin{array}{l}\text { Model } 3 \\
\mathbf{Y}=\begin{array}{l}\text { Low Service } \\
\text { Quality }\end{array}\end{array}$} \\
\hline & $\boldsymbol{\beta}$ & $\operatorname{Exp} .(\beta)$ & $\boldsymbol{\beta}$ & $\operatorname{Exp} .(\beta)$ & $\boldsymbol{\beta}$ & $\operatorname{Exp} .(\beta)$ \\
\hline X1(1) Gender & $1.02 *$ & 2.72 & 0.09 & 1.09 & -0.19 & 0.83 \\
\hline X2(1) Religion & $1.59^{*}$ & 4.88 & -0.29 & 0.75 & -1.09 & 0.34 \\
\hline X3(1) Marital status & -0.89 & 0.41 & 0.79 & 2.22 & 20.03 & 0.00 \\
\hline X4(1) Education & -2.55 & 0.78 & 0.32 & 1.38 & 0.41 & 1.51 \\
\hline X5(1) Return & 0.19 & 1.21 & $1.27 * *$ & 3.58 & 0.29 & 1.34 \\
\hline X6(1) Avoid riba & $0.853^{*}$ & 2.35 & 0.04 & 1.04 & -0.51 & 0.61 \\
\hline X7(1) Service quality & $-1.06^{*}$ & 0.35 & $1.16^{* *}$ & 3.18 & 0.49 & 1.63 \\
\hline X8(1) Conventional account & -0.12 & 0.89 & $-0.70^{*}$ & 0.50 & 0.07 & 1.08 \\
\hline Nagelkerke R-Sq & \multicolumn{2}{|l|}{$27.3 \%$} & \multicolumn{2}{|l|}{$20.0 \%$} & \multicolumn{2}{|l|}{$10.5 \%$} \\
\hline Hesmer-Lemeshow $\left(\chi^{2}\right)$ & \multicolumn{2}{|l|}{19.156} & \multicolumn{2}{|l|}{11.422} & \multicolumn{2}{|c|}{13.924} \\
\hline
\end{tabular}

in Y1 can be explained by the predictors. The Hosmer-Lemeshow test is to measure the goodness of fit of the overall model whereby its null-hypothesis is that 'the model fits the data'. Therefore, since the Hosmer-Lemeshow statistics is not significant, it can be concluded that the hypothesis of 'model fits the data' cannot be rejected statistically. The equation for Model 1 is written in Equation (6) below:

$\log \left(\frac{\mathrm{p}}{1-\mathrm{p}}\right)=-1.252+1.02 \mathrm{x}_{1}+1.59 \mathrm{x}_{2}+0.853 \mathrm{x}_{6}-1.06 \mathrm{x}_{7}$

For Model 2 where Y2 is uncompetitive return, the significant driving factors are patronizing Islamic bank is to gain better return X5(1), patronizing Islamic bank to experience better service quality $\mathrm{X} 7(1)$ and having both Islamic and conventional banking accounts. The Nagelkerke R-Square is 0.2 which indicates that $20 \%$ of variation in Y2 can be explained by the predictors and its chi-squared for Hosmer-Lemeshow Test is 11.422 which confirms that 'the model fits the data'. Unfortunately, Model 3 shows no evidence to say that any factors could significantly influencing the decision of Islamic banking customers to withdraw their deposits when they encounter a situation of low service quality. The equation for Model 2 is written in equation (7) and Model 3 is not displayed due to its insignificant model:

$\log \left(\frac{p}{1-p}\right)=-0.434+1.27 x_{5}+1.16 x_{7}-0.7 x_{8}$

With regard to the interpretation of the model, logistic regression uses the odd-ratios or the exp. $(\beta)$ to explain the probability resulted from the model. It is shown in Model 1 that the probability of Male customers to withdraw is 2.72 times higher than Female customers and the probability of Muslim customers to withdraw is 4.88 times higher than Non-Muslim customers. As anticipated, customers who are looking for banking activities but at the same time trying to avoid riba would have greater possibility to withdraw money from Islamic bank due to non-shariah compliance issues. It is 
2.35 times higher than those customers with different motivation. Furthermore, negative relationship between Y1 and X8(1) shows that customers looking for higher quality of services would leave the bank due to non-shariah compliance issues.

Odd-ratios from Model 1 indicate that; (i) Islamic banks could use "female approach" in order to instill trust and loyalty among their customers; (ii) customers had considered shariah as an important part of service quality in Islamic banking industry, and thus; (iii) Islamic banks should work harder in order to have original Islamic products and not merely mimicking conventional products.

Odd-ratios in Model 2 show that customers who are looking for better service quality and higher return before patronizing Islamic bank are tend to withdraw their deposit due to uncompetitive return received. The probability of depositors seeking for better service quality to withdraw is 3.18 times higher than those otherwise. Similarly, the probability of depositors motivated by higher return to withdraw is 3.58 times higher than those with different motivations.

Furthermore, customers with multiple account or having conventional and Islamic banking account at the same time will have 2 times higher possibility to withdraw their deposit due to uncompetitive return received. Findings in Model 2 indicate that; (i) return and service quality are considered by the customers as two inseparable factors, and (ii) Islamic banks must be able to at least maintain its competitive returns given to customers by maintaining its good performance.

Another interesting finding from those logit models developed in this study is the probability of an individual customer with certain characteristics to withdraw their deposit due to encountering the above-mentioned three unexpected situations. In order to get Equation (5) or the probability from one bank customer (p) to withdraw due to certain reasons, first, the $\log (\mathrm{p} / 1-\mathrm{p})$ value need to be put as the power of the e (i.e. 2.71). After that the probability can be calculated through Equation (2).

For instance, first scenario in Model 1, the probability of a male $\left(x_{1}=1\right)$ Muslim $\left(x_{2}=1\right)$ customer who is trying to avoid riba $\left(x_{6}=1\right)$ and looking for better service quality $\left(x_{7}=1\right)$ to withdraw his deposit due to non-shariah compliance issues is:

$$
\log \left(\frac{\mathrm{p}}{1-\mathrm{p}}\right)=-1.252+1.02(1)+1.59(1)+0.853(1)-1.06(1)=1.151
$$

Then, $e^{\log (\mathrm{p} / 1-\mathrm{p})}=e^{1.151}=3.15$; hence, his probability to withdraw is $\mathrm{p}=[3.15 /(1+3.15)]=0.76$ or $76 \%$. Meanwhile, the probability of a female $\left(x_{1}=0\right)$ non-Muslim $\left(x_{2}=0\right)$ customer whose main motivation is neither to avoid riba $\left(x_{6}=0\right)$ nor looking for better service quality $\left(x_{7}=0\right)$ to withdraw her deposit due to non-shariah compliance issues is only $22.3 \%$. Table 8 provides probability of deposit withdrawal from individual with different attributes in Model 1.

As for Model 2, the probabilities are provided in Table 9. For example, it is predicted that the probability of a customer possessing Islamic and conventional account $\left(x_{8}=1\right)$ as well as looking for higher return $\left(x_{5}=1\right)$ and better service quality $\left(x_{7}=1\right)$ is $78.4 \%$ to withdraw his deposit from Islamic bank due to uncompetitive return.

Overall the findings confirm that deposit withdrawal is a real future threat for Islamic banking in Brunei Darussalam. The triggers of the withdrawal action are negative issues of shariah compliancy upon the products and services, uncompetitive return, and bad service quality. However, not every customer will be affected by those triggers. Only customers with certain individual attributes will respond to a specific trigger. As the managerial implications of the findings, Islamic banks must be able to identify the attributes attached to their existing customers in order to maintain the good relationship between them and the bank. Hence, could mitigate the potential withdrawal risk to emerge. 
Table 8. Probability of deposit withdrawal in Model 1

\begin{tabular}{|c|c|c|c|c|c|c|c|c|c|c|c|}
\hline \multirow{3}{*}{ Scenario } & Constant & X1 & $\mathrm{X} 2$ & X6 & X7 & \multirow{3}{*}{\multicolumn{2}{|c|}{$\log \left(\frac{p}{1-p}\right)$}} & \multirow{3}{*}{$e$} & \multirow{3}{*}{$e^{\log \left(\frac{p}{1-p}\right)}$} & \multirow{3}{*}{ Prob. $=$} & \multirow{2}{*}{$e^{\log \left(\frac{p}{1-p}\right)}$} \\
\hline & & & & & & & & & & & \\
\hline & -1.252 & 1.02 & 1.59 & 0.853 & -1.06 & & & & & & $1+e^{\log \left(\frac{p}{1-p}\right)}$ \\
\hline 1 & -1.252 & 1 & 1 & 1 & 1 & 1.151 & & 2.71 & 3.15 & 0.759 & \\
\hline 2 & -1.252 & 1 & 1 & 1 & 0 & 2.211 & & 2.71 & 9.06 & 0.901 & \\
\hline 3 & -1.252 & 1 & 1 & 0 & 1 & 0.298 & & 2.71 & 1.35 & 0.574 & \\
\hline 4 & -1.252 & 1 & 0 & 1 & 1 & -0.439 & & 2.71 & 0.65 & 0.392 & \\
\hline 5 & -1.252 & 0 & 1 & 1 & 1 & 0.131 & & 2.71 & 1.14 & 0.533 & \\
\hline 6 & -1.252 & 1 & 1 & 0 & 0 & 1.358 & & 2.71 & 3.87 & 0.795 & \\
\hline 7 & -1.252 & 1 & 0 & 0 & 1 & -1.292 & & 2.71 & 0.28 & 0.216 & \\
\hline 8 & -1.252 & 0 & 0 & 1 & 1 & -1.459 & & 2.71 & 0.23 & 0.189 & \\
\hline 9 & -1.252 & 1 & 0 & 0 & 0 & -0.232 & & 2.71 & 0.79 & 0.442 & \\
\hline 10 & -1.252 & 0 & 1 & 0 & 0 & 0.338 & & 2.71 & 1.40 & 0.583 & \\
\hline 11 & -1.252 & 0 & 0 & 1 & 1 & -1.459 & & 2.71 & 0.23 & 0.189 & \\
\hline 12 & -1.252 & 0 & 0 & 0 & 1 & -2.312 & & 2.71 & 0.10 & 0.091 & \\
\hline 13 & -1.252 & 0 & 0 & 0 & 0 & -1.252 & & 2.71 & 0.29 & 0.223 & \\
\hline
\end{tabular}

Table 9. Probability of deposit withdrawal in Model 2

\begin{tabular}{|c|c|c|c|c|c|c|c|c|c|}
\hline \multirow{3}{*}{ Scenario } & Constant & X5 & $\mathrm{X} 7$ & $\mathrm{X8}$ & \multirow{3}{*}{$\log \left(\frac{p}{1-p}\right)$} & \multirow{3}{*}{$e$} & \multirow{3}{*}{$e^{\log \left(\frac{p}{1-p}\right)}$} & \multirow{3}{*}{ Prob. $=$} & \\
\hline & & & & & & & & & $e^{(1-p)}$ \\
\hline & -0.434 & 1.27 & 1.16 & -0.7 & & & & & $\left(1+e^{\log \left(\frac{p}{1-p}\right)}\right.$ \\
\hline 1 & -0.434 & 1 & 1 & 1 & 1.296 & 2.71 & 3.64 & 0.784 & \\
\hline 2 & -0.434 & 1 & 1 & 0 & 1.996 & 2.71 & 7.31 & 0.880 & \\
\hline 3 & -0.434 & 1 & 0 & 1 & 0.136 & 2.71 & 1.15 & 0.534 & \\
\hline 4 & -0.434 & 0 & 1 & 1 & 0.026 & 2.71 & 1.03 & 0.506 & \\
\hline 5 & -0.434 & 1 & 0 & 0 & 0.836 & 2.71 & 2.30 & 0.697 & \\
\hline 6 & -0.434 & 0 & 0 & 1 & -1.134 & 2.71 & 0.32 & 0.244 & \\
\hline 7 & -0.434 & 0 & 0 & 0 & -0.434 & 2.71 & 0.65 & 0.393 & \\
\hline
\end{tabular}

\section{CONCLUSION}

This paper explores the influence of individual characteristics in decision making process with regard to deposit withdrawal when they encounter three different situations; (i) non-shariah compliance issues upon products and services, (ii) uncompetitive return, and (iii) low service quality. As anticipated, the findings provide evidence that customers with different characteristics shall react differently upon their deposit withdrawal decision when they encounter the three situations mentioned above. This implies that the future risk of deposit withdrawal is real and there is no "one shoe fits all" marketing strategy. One of the managerial implications is that Islamic banking must provide different marketing 
strategies in order to retain their existing customers and attract new ones with different backgrounds and characteristics.

The researchers realize that this study is not without limitations. Therefore, it provides suggestions for other researchers who are interested in the same area of study in order to produce more robust findings. The suggestions are (i) to increase the sample size so the opinion of the society towards the topic could be captured better, (ii) to use more sophisticated method of analysis such as artificial neural networks, and (iii) to distinguish the analysis between customers having Islamic banking account only and customers with banking account in both Islamic and conventional banks. 


\section{REFERENCES}

Abduh, M. (2011). Islamic Banking Service Quality and Withdrawal Risk: The Indonesian Experience. International Journal of Excellence in Islamic Banking and Finance, 1(2), 1-15.

Abduh, M. (2014). Withdrawal Behavior of Malaysian Islamic Bank Customers: Empirical Evidence from Three Major Issues. Journal of Islamic Banking and Finance, 31(4), 43-54.

Abduh, M. (2015). Determinants of Islamic Banking Deposit: Empirical Evidence from Indonesia. Middle East Journal of Management, 2(3), 240-251. doi:10.1504/MEJM.2015.072462

Abduh, M. (2016). Islamic Banking Service Quality and Deposit Withdrawal Risk: Evidence from Brunei Darussalam. Islamic Banking and Finance Review, 3, 1-11.

Abduh, M. (2017). Deposit Withdrawal Behavior in Islamic Banking. Bandar Seri Begawan: UNISSA Press.

Abduh, M. (2018). Assessing the Performance of Islamic Banking in Brunei Darussalam: Evidence from 2011 to 2016. Al-Shajarah, (Special Issue: Islamic Banking and Finance), 171-189.

Abduh, M., Dahari, Z., \& Omar, M. A. (2012). Bank Customer Classification in Indonesia: Logistic Regression vis-à-vis Neural Networks. World Applied Sciences Journal, 18(7), 933-938.

Abduh, M., Omar, M. A., \& Duasa, J. (2011). The Impact of Crisis and Macroeconomic Variables towards Islamic Banking Deposits. American Journal of Applied Sciences, 8(12), 1413-1418. doi:10.3844/ajassp.2011.1378.1383

Abduh, M., \& Omarov, D. (2013). Muslim's Awareness and Willingness to Patronize Islamic Banking in Kazakhstan. Journal of Islamic Banking and Finance, 30(3), 16-24.

Afsar, B., Rehman, Z., Qureshi, J. A., \& Shahjehan, A. (2010). Determinants of Customer Loyalty in the Banking Sector: The case of Pakistan. African Journal of Business Management, 4(6), 1040-1047.

Ahmed, H. (2002). A Microeconomic Model of an Islamic Bank. Jeddah: Islamic Research and Training Institute.

Ahmed, H. (2003, September). Withdrawal Risk in Islamic Banks, Market Discipline and Bank Stability. Paper presented at the International Conference on Islamic Banking: Risk Management, Regulation and Supervision, Jakarta, Indonesia. Academic Press.

Archer, S., \& Karim, R. A. A. (2009). Profit-Sharing Investment Accounts in Islamic Banks: Regulatory Problems and Possible Solutions. Journal of Banking Regulation, 10(4), 300-306.

Beerli, A., Martín, J. D., \& Quintana, A. (2004). A Model of Customer Loyalty in the Retail Banking Market. European Journal of Marketing, 38(1/2), 253-275.

Currie, L. (2004). The Behavior of Deposits. Journal of Economic Studies (Glasgow, Scotland), 31(3/4), 340-346.

Gerard, P., \& Cunningham, J. B. (2001). Singapore Undergraduates: How They Choose Which Bank to Patronize. International Journal of Bank Marketing, 19(3), 104-114.

Gilkeson, J. H., List, J. A., \& Ruff, C. K. (1999). Evidence of Early Withdrawal in Time Deposits Portfolios. Journal of Financial Services Research, 15(2), 103-122. doi:10.1023/A:1008071719082

Gilkeson, J. H., \& Ruff, C. K. (1996). Valuing the Withdrawal Option in Retail CD Portfolios. Journal of Financial Services Research, 10, 333-358.

Haron, S., \& Ahmad, N. (2000). The effects of conventional interest rates and rate of profits on funds deposited with Islamic banking system in Malaysia. International Journal of Islamic Financial Services, 1(4), 1-7.

Hosmer, D. W., \& Lemeshow, S. (2000). Applied Logistic Regression. U.S.A: John Wiley and Sons. doi:10.1002/0471722146

Iqbal, M., Ahmad, A., \& Khan, T. (1998). Challenges facing Islamic Banking. Jeddah: Islamic Research and Training Institute.

Mahmoud, L. O. M., \& Abduh, M. (2014). The Role of Awareness in Islamic Bank Patronizing Behavior of Mauritanian: An Application of TRA. Journal of Islamic Finance, 3(2), 30-38. doi:10.12816/0025103 
Muhamad Abduh was born in Jakarta, May 1981. He completed his Bachelor of Science (Statistics) from Bogor Agricultural University, Indonesia, in September 2004 and his first master's degree, Magister Hukum Islam (Fiqh Al-Mu'amalat) from Ibn Khaldun University, Bogor, Indonesia, in September 2006. He completed his second master's degree, Master of Economics (Islamic Economics) from the International Islamic University Malaysia (IIUM) in June 2009. Under the supervision of Prof. Dato' Dr. Mohd Azmi Omar, former IRTI-IDB Director based in Jeddah, Abduh completed his PhD in Business Administration from IIUM with specialization in Islamic Banking and Finance in December 2011. Abduh has written more than 50 journal articles and four books in the area of Islamic finance. The books were published by Fath-Publication (Indonesia) in 2009, WILEY (New Jersey, USA) in 2013, IIUM Press (Kuala Lumpur) in 2016, and UNISSA Press (Brunei Darussalam) in 2017. Prior to joining the UBD School of Business and Economics (UBDSBE), Abduh was an Assistant Professor at the IIUM Institute of Islamic Banking and Finance (IliBF) and the Head of Research for the Institute from 2012 to 2015. 